\title{
RECORD OF Digonogastra sp. (HYMENOPTERA: BRACONIDAE) PARASITIZING Diatraea flavipennella (LEPIDOPTERA: CRAMBIDAE) IN ALAGOAS, BRAZIL ${ }^{1}$
}

\author{
ELLEN CARINE NEVES VALENTE ${ }^{2}$, SÔNIA MARIA FORTI BROGLIO ${ }^{2}$, NIVIA DA SILVA DIAS-PINI ${ }^{3 *}$, ANDRÉ \\ SUÊLDO TAVARES DE LIMA ${ }^{4}$, LÍGIA BROGLIO MICHELETTI ${ }^{2}$
}

\begin{abstract}
The aim of this study is to document the heretofore unrecorded natural occurrence of the larval parasitoid Digonogastra sp. on Diatraea flavipennella Box, 1931 (Lepidoptera: Crambidae) in sugarcane fields. The collections were made in the Usina Santa Clotilde area, in Rio Largo municipality, Alagoas State, Brazil. This is the first record of Digonogastra sp. parasitizing caterpillar of D. flavipennella in Brazil. The parasitism rate was found to be $14.06 \%$. The occurrence of this parasitoid indicates potential for natural regulation of that pest in sugarcane crop.
\end{abstract}

Keywords: Idiobiont. Occurrence. Parasitoid. Sugarcane.

\section{REGISTRO DE Digonogastra sp. (HYMENOPTERA: BRACONIDAE) PARASITANDO Diatraea flavipennella (LEPIDOPTERA: CRAMBIDAE) EM ALAGOAS, BRASIL}

RESUMO - O objetivo deste estudo foi registrar a ocorrência natural do parasitoide larval Digonogastra sp. em Diatraea flavipennella Box, 1931 (Lepidoptera: Crambidae) em cana-de-açúcar. As coletas foram realizadas na Usina Santa Clotilde (9 $25^{\prime}$ 'S, $35^{\circ} 49^{\prime} \mathrm{W}, 127 \mathrm{~m}$ de altitude), no município de Rio Largo, Estado de Alagoas, Brasil. Este é o primeiro registro do gênero Digonogastra parasitando lagartas de D. flavipennella no Brasil. A taxa de parasitismo verificada foi de 14,06\%. A ocorrência deste parasitoide indica um potencial de regulação natural da referida praga em cana-de-açúcar.

Palavras-chave: Idiobionte. Ocorrência. Parasitoide. Cana-de-açúcar.

${ }^{2}$ Center of Agricultural Science, Universidade Federal de Alagoas, Maceió, AL, Brazil; ellencvalente@yahoo.com.br, soniamfbroglio@gmail.com, ligia_micheletti@hotmail.com.

${ }^{3}$ Embrapa Agroindústria Tropical, Fortaleza, CE, Brazil; nivia.dias@embrapa.br.

${ }^{4}$ Department of Agroecology, Instituto Federal de Educação, Ciência e Tecnologia de Alagoas, Maragogi, AL, Brazil; andresueldo@ig.com.br.
} 


\section{INTRODUCTION}

Digonogastra Viereck, 1912 (Hymenoptera: Braconidae: Braconinae) is an idiobiont ectoparasitoid whose main hosts are larvae of Crambidae, Pyralidae, Prodoxidae, and Psychidae (Lepidoptera) and Curculionidae and Cerambycidae (Coleoptera) (BARONIO et al., 2012; CRABB; PELLMYR, 2006; YU; ACHTERBERG; HORSTMANN, 2012). The genus includes about 260 described species with Afrotropical, Nearctic, and Neotropical distribution (YU; ACHTERBERG; HORSTMANN, 2012).

Species of this genus have been studied in biological control programs of Eoreuma loftini (Lepidoptera: Pyralidae) in sugarcane in Texas, and several species of Diatraea in USA and Latin America (SMITH; BROWNING; BENNETT, 1987; WHARTON et al., 1989).

The sugarcane borer Diatraea flavipennella Box, 1931 (Lepidoptera: Crambidae) is an important pest in sugarcane plantations in northeastern Brazil. Their control has been performed mainly through the use of larval parasitoid Cotesia flavipes (Hymenoptera: Braconidae) by means of inundative releases (DIAS-PINI et al., 2012; SILVA et al., 2012). The control with this parasitoid has shown a significant increase of $26 \%$ of parasitism on Diatraea spp. in cane fields of Northeast Brazil (BOTELHO; MACEDO, 2002). The number of parasitoids that control the species of Diatraea is vast. In Brazil, in addition to $C$. flavipes, other biological control programs were implemented such as the Metagonistylum minense Towns, 1927 and Paratheresia claripalpis (Diptera: Tachinidae) (BOTELHO, 1992).

However, there is little information available regarding the parasitoids associated with $D$. flavipennella. Dias et al. (2011) recorded the egg parasitoid Telenomus alecto Crawford, 1914 (Hymenoptera: Scelionidae) on D. flavipennella in the sugarcane plantations of the State of Alagoas, Brazil.

The objective of this study was to record the occurrence of the larval parasitoid of the genus
Digonogastra (Hymenoptera: Braconidae) on D. flavipennella in sugarcane in the State of Alagoas, Brazil.

\section{MATERIAL AND METHODS}

The experiment was performed in the Usina Santa Clotilde area $\left(9^{\circ} 25^{\prime} \mathrm{S}, 35^{\circ} 49^{\prime} \mathrm{W}, 127 \mathrm{~m}\right.$ above sea level), in the municipality of Rio Largo, Alagoas State, Brazil. An artificial infestation was performed with caterpillar of $D$. flavipennella reared on an artificial diet of soybean meal, wheat germ, sugar, vitamin solution, Wesson salts, ascorbic acid, and water (VALENTE et al., 2014).

One hundred pieces of sugarcane culms (Saccharum officinarum variety SP 79-1011) measuring $50 \mathrm{~cm}$ in length were perforated using a drilling machine, creating $5 \mathrm{~mm}$ diameter diagonal holes, through which a single third-instar caterpillar was introduced with a soft brush (no. 0). Twentyfour hours after the artificial infestation, the culms were distributed in the field. An area of $225 \mathrm{~m} \times 110$ $\mathrm{m}$ was marked and divided into 10 parcels of $4.5 \mathrm{~m} \times$ $2.0 \mathrm{~m}$ each. In each parcel, ten culms were put in the center, placed equidistantly in rows of $20 \mathrm{~cm}$ distance from each other. The culms were tagged and fixed using a string attached to sugarcane clumps. The methodology used here is similar to the one described in Volpe et al. (2011). The environmental conditions were on average $26^{\circ} \mathrm{C}$ temperature and $62 \%$ humidity.

After five days of exposure to parasitism, the culms were collected and brought to the Agricultural Entomology Laboratory at the Federal University of Alagoas to remove caterpillars. The caterpillars were individually placed in Petri dishes $(6.0 \mathrm{~cm}$ diameter $)$ containing artificial diet to keep them alive and observe the parasitism (Figure 1). Petri dishes were maintained under favorable environmental conditions of $26 \pm 1^{\circ} \mathrm{C}, 70 \pm 10 \%$ humidity, and $12 \mathrm{~h}$ photophase until the emergence of parasitoids or development of the borer.

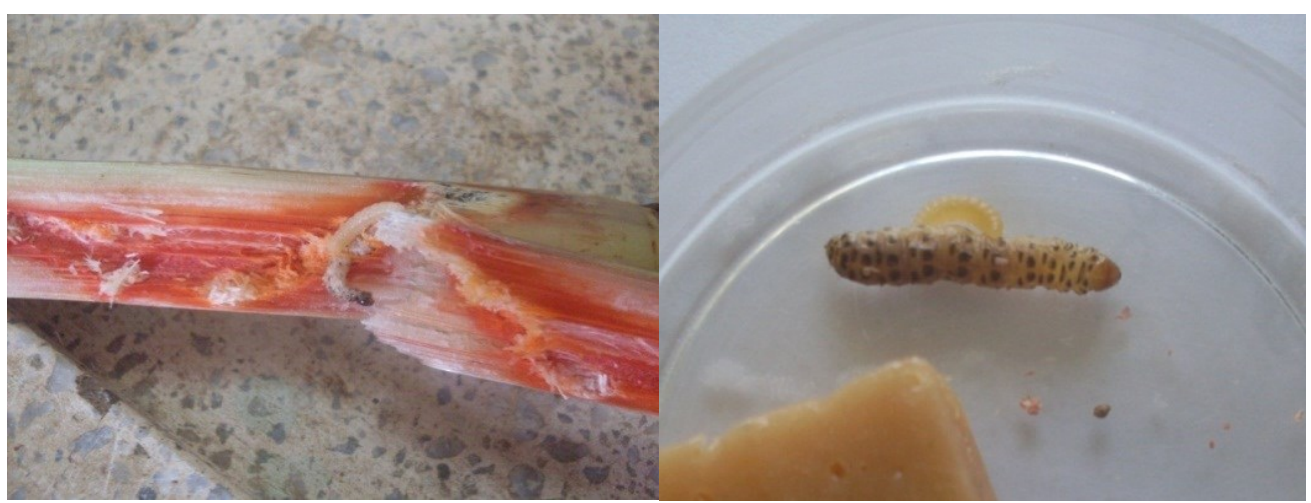

Figure 1. Diatraea flavipennella caterpillar parasitized in sugarcane and in artificial diet. 


\section{RESULTS AND DISCUSSION}

From the total of 100 caterpillars of $D$. flavipennella distributed in the field, 64 were recovered, of which $14.06 \%$ were parasitized. The parasitoid adults were sent to Dr. Angélica Maria Penteado-Dias at the Federal University of São Carlos, and were noted as an unidentified species of Digonogastra (Figure 2).

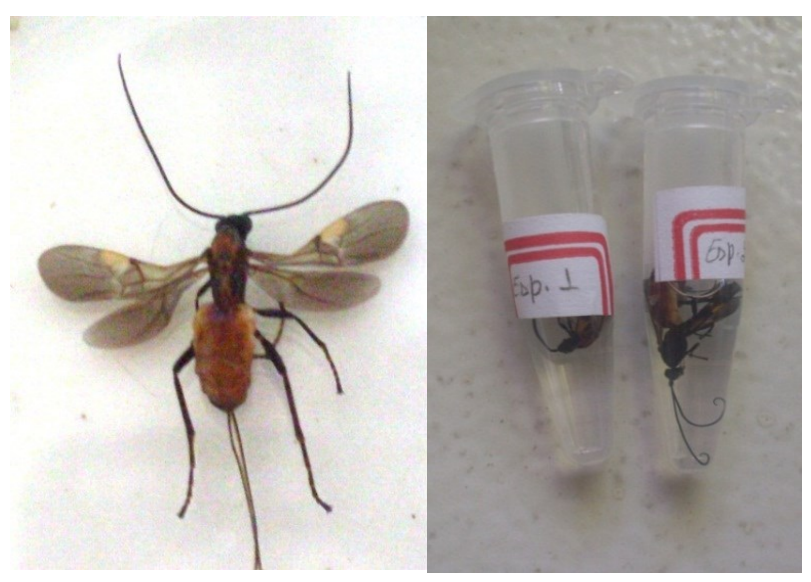

Figure 2. Adult of Digonogastra sp. and copies sent for identification.

This is the first record of this parasitoid genus associated with $D$. flavipennella in Brazil. Literature about this genus of Braconidae is scarce. According to Quicke (1988), several species of Digonogastra parasitize Diatraea spp. and other species of Pyralidae (= Crambidae). Diatraea grandiosella Dyar, 1911, D. magnifactella Dyar, 1911, D. lineolata, D. considerata Heinrich, 1931, and D. saccharalis (Lepidoptera: Crambidae) are known hosts of Digonogastra kimballi (QUICKE, 1988) (Hymenoptera: Braconidae). This study shows, for the first time, the parasitism of $D$. flavipennella by an unidentified species of Digonogastra in Brazil, which may offer a new perspective for the use of this parasitoid in the biological control of $D$. flavipennella in cane fields.

\section{CONCLUSIONS}

This is the first record of this parasitoid genus associated with D. flavipennella in Brazil.

\section{ACKNOWLEDGMENTS}

The authors are grateful to Fundação de Amparo à Pesquisa do Estado de Alagoas (FAPEAL) —process no. PEB-20110325-002-0004-0041-for financial support, Central Açucareira Santo Antônio, Usina Santa Clotilde, Valmir Antônio Costa, and Angélica M. Penteado-Dias, whose support was essential for the realization of this study.

\section{REFERENCES}

BARONIO, C. A. et al. Bioecologia e controle do bicho do cesto Oiketicus kirbyi (Guilding, 1927) (Lepidoptera: Psychidae) em pessegueiro e videira. Bento Gonçalves: Embrapa Uva e Vinho, 2012. 9 p. (Comunicado Técnico, 132).

BOTELHO, P. S. M. Quinze anos de controle biológico de Diatraea saccharalis utilizando parasitoides. Pesquisa Agropecuária Brasileira, Brasília, v. 27, s/n., p. 255-262, 1992.

BOTELHO, P. S. M.; MACEDO, N. Cotesia flavipes para o controle de Diatraea saccharalis. In: PARRA, J. R. P. et al. (Eds.). Controle biológico no Brasil: parasitóides e predadores. São Paulo: Manole, 2002, cap. 25, p. 477-494.

CRABB, B. A.; PELLMYR, O. Impact of the third trophic level in an obligate mutualism: do yucca plants benefit from parasitoids of yucca moths? International Journal of Plant Sciences, Chicago, v. 167, n. 1, p. 119-124, 2006.

DIAS, N. S. et al. Ocorrência de Telenomus alecto Crawford, 1914 (Hymenoptera: Scelionidae) em ovos de Diatraea spp. (Lepidoptera: Crambidae) em cana-de-açúcar no estado de Alagoas, Brasil. Idesia, Arica, v. 29, n. 3, p. 95-97, 2011.

DIAS-PINI, N. S. et al. Biological characteristics of Telenomus alecto and Trichogramma galloi reared on eggs of the sugarcane borer Diatraea flavipennella. Revista Brasileira de Entomologia, Curitiba, v. 56, n. 4, p. 515-518, 2012.

QUICKE, D. L. J. A new genus and species of Braconinae (Hymenoptera: Braconidae) parasitic on Diatraea sp. (Lepidoptera: Pyralidae) from Ecuador. 
Bulletin of Entomological Research, Brisbane, v. 78, n. 1, p. 15-18, 1988.

SILVA, C. C. M. et al. Preference of the parasitoid Cotesia flavipes (Cam.) (Hymenoptera: Braconidae) for Diatraea (Lepidoptera: Crambidae). Acta Scientiarum Agronomy, Maringá, v. 34, n. 1, p. 23 27, 2012.

SMITH, J. W.; BROWNING, H. W.; BENNETT, F. D. Allorhogas pyralophagus (Hym: Braconidae), a gregarious external parasite imported into Texas, USA, for biological control of the stalkborer Eoreuma loftini (Lep.: Pyralidae) on sugar cane. Biocontrol, Dordrecht, v. 32, n. 5, p. 477-482, 1987.

VALENTE, E. C. N. et al. Efeito de fungos entomopatogênicos sobre formas imaturas de Diatraea flavipennella (Lepidoptera: Crambidae). Revista Brasileira de Agroecologia, Pelotas, v. 9, n. 1, p. 1-11, 2014.

VOLPE, H. X. L. et al. Metodologia para avaliar liberações dirigidas de Cotesia flavipes. Cadernos de Agroecologia, Porto Alegre, v. 6, n. 2, p. 1-6, 2011.

WHARTON, R. A. et al. Two new species of Digonogastra Viereck (Hymenoptera: Braconidae) parasitic on Neotropical pyralid borers (Lepidoptera) in maize, sorghum and sugarcane. Bulletin of Entomological Research, Cambridge, v. 79, n. 3, p. 401-410, 1989.

YU, D. S.; ACHTERBERG, C.; HORSTMANN, K. Taxapad Ichneumonoidea. Vancouver, [s. n.], 2012. Disponível em: <http://www.taxapad.com/ local.php? showpage=taxonomy $>$. Acesso em: 21 mai. 2017. 